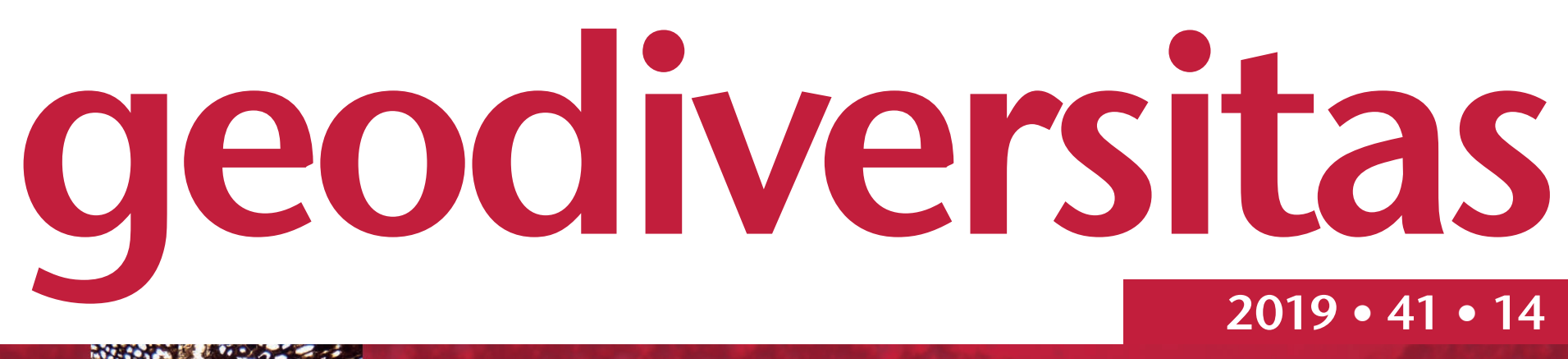
(1)

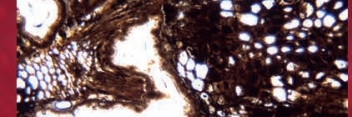

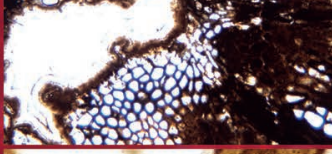
Lis intra 2 and evolutionary implications Anatomy, affinities, - of new silicified stems of Sphenophyllum 1. Brongniart, 1828 from the early Carboniferous कorgestivity

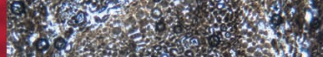
(Mississippian) of France and Germany

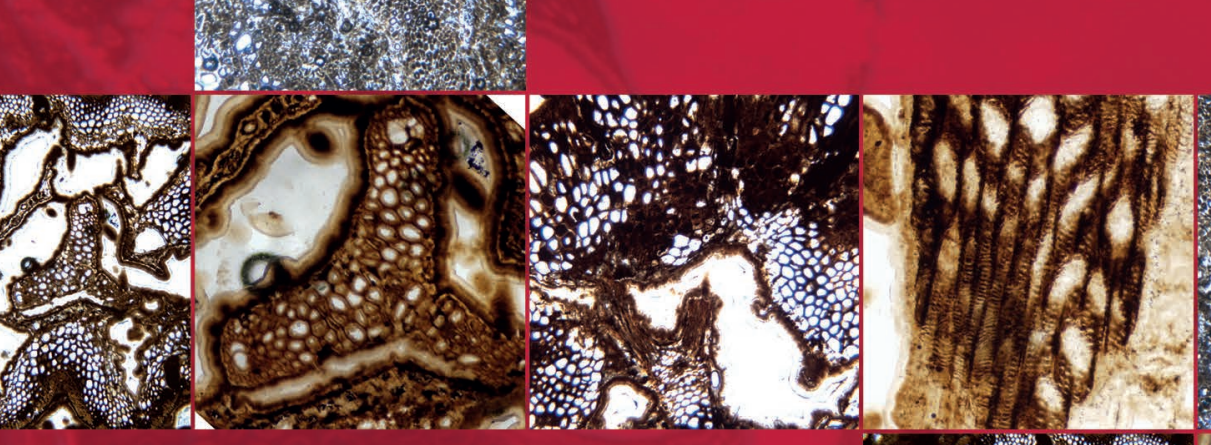

Hugues TERREAUX DE FELICE, Anne-Laure DECOMBEIX \& Jean GALTIER

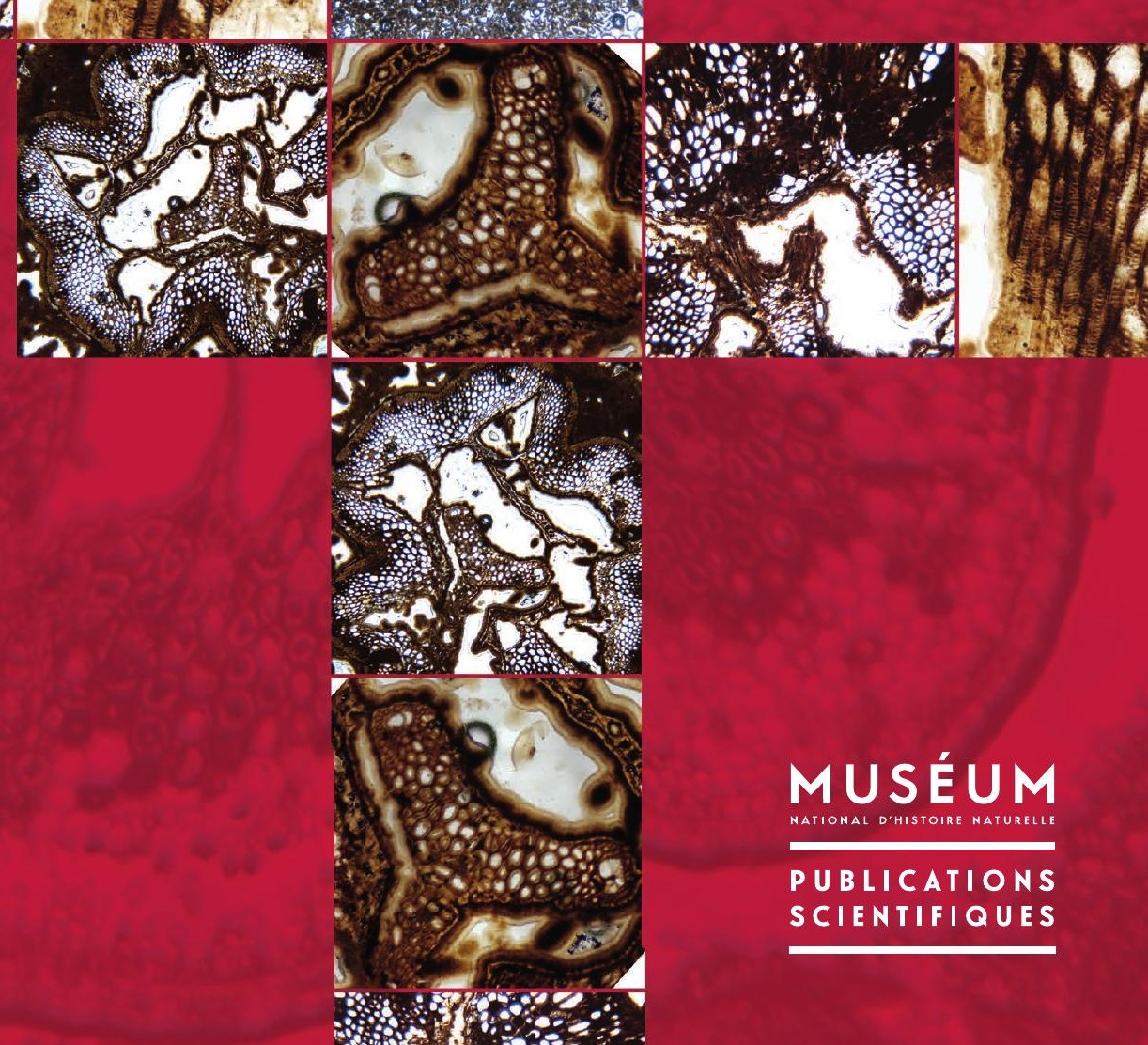


DiRECTEUR DE LA PUBLICATION: Bruno David,

Président du Muséum national d'Histoire naturelle

RÉdACTEUR EN CHEF / EDITOR-IN-CHIEF: Didier Merle

ASSISTANTS DE RÉDACTION / AsSISTANT EDITORS: Emmanuel Côtez (geodiv@mnhn.fr); Anne Mabille

Mise EN PAGE / PAGE LAYOUT: Emmanuel Côtez

COMITÉ SCIENTIFIQUE / SCIENTIFIC BOARD:

Christine Argot (MNHN, Paris)

Beatrix Azanza (Museo Nacional de Ciencias Naturales, Madrid)

Raymond L. Bernor (Howard University, Washington DC)

Alain Blieck (chercheur CNRS retraité, Haubourdin)

Henning Blom (Uppsala University)

Jean Broutin (UPMC, Paris)

Gaël Clément (MNHN, Paris)

Ted Daeschler (Academy of Natural Sciences, Philadelphie)

Bruno David (MNHN, Paris)

Gregory D. Edgecombe (The Natural History Museum, Londres)

Ursula Göhlich (Natural History Museum Vienna)

Jin Meng (American Museum of Natural History, New York)

Brigitte Meyer-Berthaud (CIRAD, Montpellier)

Zhu Min (Chinese Academy of Sciences, Pékin)

Isabelle Rouget (UPMC, Paris)

Sevket Sen (MNHN, Paris)

Stanislav Štamberg (Museum of Eastern Bohemia, Hradec Králové)

Paul Taylor (The Natural History Museum, Londres)

COUVERTURE / COVER:

Made from the figures of the article.

Geodiversitas est indexé dans / Geodiversitas is indexed in:

- Science Citation Index Expanded (SciSearch ${ }^{\circledR}$ )

- ISI Alerting Services ${ }^{\circledR}$

- Current Contents ${ }^{\circledR}$ / Physical, Chemical, and Earth Sciences ${ }^{\circledR}$

- Scopus ${ }^{\circledR}$

Geodiversitas est distribué en version électronique par / Geodiversitas is distributed electronically by:

- BioOne ${ }^{\circledR}$ (http://www.bioone.org)

Les articles ainsi que les nouveautés nomenclaturales publiés dans Geodiversitas sont référencés par / Articles and nomenclatural novelties published in Geodiversitas are referenced by:

- ZooBank ${ }^{\circledR}$ (http://zoobank.org)

Geodiversitas est une revue en flux continu publiée par les Publications scientifiques du Muséum, Paris Geodiversitas is a fast track journal published by the Museum Science Press, Paris

Les Publications scientifiques du Muséum publient aussi / The Museum Science Press also publish:

Adansonia, Zoosystema, Anthropozoologica, European Journal of Taxonomy, Naturae, Cryptogamie sous-sections Algologie, Bryologie, Mycologie.

Diffusion - Publications scientifiques Muséum national d'Histoire naturelle

CP $41-57$ rue Cuvier F-75231 Paris cedex 05 (France)

Tél. : 33 (0)1407948 05 / Fax: 33 (0)14079 3840

diff.pub@mnhn.fr / http://sciencepress.mnhn.fr

(C) Publications scientifiques du Muséum national d'Histoire naturelle, Paris, 2019

ISSN (imprimé / print): 1280-9659/ ISSN (électronique / electronic): 1638-9395 


\title{
Anatomy, affinities, and evolutionary implications of new silicified stems of Sphenophyllum Brongniart, 1828 from the early Carboniferous (Mississippian) of France and Germany
}

\author{
Hugues TERREAUX DE FELICE \\ Department of fundamental sciences, University of Quebec in Chicoutimi, Quebec (Canada) \\ Anne-Laure DECOMBEIX \\ AMAP, Univ. Montpellier, CIRAD, CNRS, INRA, IRD, F-34098 Montpellier (France) \\ and Department of Ecology and Evolutionary Biology, and Natural History Museum and \\ Biodiversity Institute, University of Kansas, Lawrence, KS 66045-7534 (United States) \\ anne-laure.decombeix@cirad.fr (corresponding author) \\ Jean GALTIER \\ AMAP, Univ. Montpellier, CIRAD, CNRS, INRA, IRD, F-34098 Montpellier (France) \\ Submitted on 22 November 2018 | accepted on 26 March 2019 | published on 29 August 2019
}

KEY WORDS

Tournaisian, anatomy,

anatomy,
Sphenophyllales, wood.
urn:Isid:zoobank.org:pub:BBDD0C3B-5CF2-48FF-B684-3457EF2DA8B7

Terreaux de Felice H., Decombeix A.-L. \& Galtier J. 2019. - Anatomy, affinities, and evolutionary implications of new silicified stems of Sphenophyllum Brongniart, 1828 from the early Carboniferous (Mississippian) of France and Germany. Geodiversitas 41 (14): 587-599. https://doi.org/10.5252/geodiversitas2019v41a14. http://geodiversitas.com/41/14.

\section{ABSTRACT}

Sphenophyllum Brongniart, 1828 is the best-known representative of Sphenophyllales, an extinct order of small plants belonging to the Sphenophytes, the group that contains extant horsetails. Sphenophyllum is known from the Devonian to the Triassic, but most specimens are late Carboniferous in age and the anatomy of specimens present at other times is poorly known because most are preserved in compression/impressions. The Lower Carboniferous (Tournaisian) deposits of Montagne Noire in France and Thuringia in Germany contain impressions attributed to Sphenophyllum but also a few rare permineralized specimens. In this study, we describe in detail the anatomy of these specimens and compare them to other anatomically preserved Sphenophyllum species, as well as to the impressions already described in both areas. The new specimens show different developmental stages, some have a little amount of wood while the others only have primary tissues. Two specimens are branching. All are assigned to Sphenophyllum insigne Williamson. While Late Carboniferous Sphenophyllum produced a wood with a very peculiar anatomy (very large tracheids, axial system of parenchyma), that of the oldest Sphenophyllales (Devonian-Early Carboniferous) seems to be simpler and probably had different hydraulic and mechanical properties. 


\begin{abstract}
RÉSUMÉ
Anatomie, affinités et implications évolutives de nouvelles tiges silicifiées de Sphenophyllum Brongniart, 1828 du Carbonifere inférieur (Mississippien) de France et d'Allemagne.

Sphenophyllum Brongniart, 1828 est le représentant le mieux connu des Sphénophyllales, un ordre éteint de plantes de petite taille appartenant aux Sphénophytes, le groupe qui contient les prêles actuelles. Sphenophyllum est connu du Dévonien au Trias mais la plupart des spécimens datent du Carbonifère supérieur et l'anatomie des spécimens présents à d'autres périodes est très mal connue car la plupart sont conservés en compression/empreintes. Les gisements du Carbonifère inférieur (Tournaisien) de la Montagne Noire en France et de Thuringe en Allemagne contiennent des empreintes attribuées à Sphenophyllum mais aussi quelques rares spécimens perminéralisés. Dans cette étude nous décrivons en détail l'anatomie de ces spécimens et nous les comparons aux autres espèces de Sphenophyllum anatomiquement conservées ainsi qu'aux empreintes déjà décrites dans les deux régions. Les nouveaux spécimens présentent différents stades de développement, certains ayant un peu de bois tandis que d'autres ne contiennent que des tissus primaires. Deux spécimens sont ramifiés. Tous sont attribués à

MOTS CLÉS

Tournaisien, anatomie, Sphenophyllales, bois.

Sphenophyllum insigne Williamson. Alors que les Sphenophyllum du Carbonifère supérieur produisaient un bois à l'anatomie très particulière (très larges trachéides, organisation axiale du parenchyme), celui des Sphenophyllales les plus anciennes (Dévonien-Carbonifère inférieur) semble être plus simple et avait probablement des propriétés hydrauliques et mécaniques différentes.
\end{abstract}

\section{INTRODUCTION}

Sphenophyllales are an extinct group of sphenopsids, the clade represented today by the genus Equisetum Linnaeus, 1753 (horsetails). Sphenophyllales are known from the Late Devonian (416-360 Ma) to the Triassic (Taylor et al. 2009). Early representatives of the group have been reported in China and Belgium, with the genera Eviostachya Stockmans, 1948 (Leclercq 1957; Y. Wang 1993), Hamatophyton Gu \& Zhi, 1974 emend. Wang, Hao, Tian \& Xue, 2006 (Li et al. 1995; DM Wang et al. 2006a), Rotafolia Wang, Hao \& Wang, 2005 emend. Wang, Hao, Wang \& Xue, 2006 (DM Wang et al. 2005, 2006b), Xihuphyllum Chen, 1988 emend. Huang, Liu, Deng, Basinger \& Xue, 2017 (Chen 1988; Huang et al. 2017), and Sphenophyllum Brongniart, 1828 and Sphenophyllostachys Seward, 1898 (Wang et al. 2005 and references therein; Huang et al. 2018). Sphenophyllales were widespread in the equatorial belt during the Carboniferous and Permian and are an emblematic component of the coal swamp floras of that period. Members of the Sphenophyllales are all herbaceous (Taylor et al. 2009) and characterized by wedge-shaped leaves borne in whorls. The genus Sphenophyllum, erected by Brongniart in 1828, is the most abundant and probably best-known representative of the group. Reconstructions of late Carboniferous species show Sphenophyllum as a nonself-supporting plant with a scrambling habit (Galtier \& Daviero 1999; Bashforth \& Zodrow 2007). Some species have hooks on their leaves and are interpreted as climbing plants (Batenburg 1977, 1981). Unlike extant sphenopsids, Sphenophyllum had secondary xylem (wood), which was produced by a determinate vascular cambium (Eggert \& Gaunt 1973; Cichan \& Taylor 1990). The wood of the late Carboniferous-Permian species has a distinct anatomy, with very large and long tracheids and a system of vertical parenchyma cells located at the corners of tracheids and connected to the rays (e.g., Renault 1876; Williamson \& Scott 1895; Cichan 1985, 1986). Late Devonian representatives of the Sphenophyllales also produced secondary xylem but they had a simpler anatomy (Wang et al. 2005, 2006a, b).

While there are numerous specimens and species of Sphenophyllum reported from the late Carboniferous (= Pennsylvanian), there is little information about the early Carboniferous (= Mississippian) members of the genus. This is, in part, due to fewer known outcrops, most containing only compression/impression specimens. It is thus essential to gather new information on the Sphenophyllales of this period, especially their anatomy, to better understand the transition between the Late Devonian genera and the well-known Late Carboniferous Sphenophyllum.

In the Montagne Noire region of France, compression specimens of Sphenophyllum sp. have been described from Tournaisian deposits (Rowe \& Galtier 1989) and Galtier (1970) reported the presence of an anatomically preserved specimen in the flora of the Lydienne Formation. A similar situation occurs in Germany, where both compressions (Meyer-Berthaud \& Rowe 1997) and anatomically preserved specimens (Solms-Laubach 1896: 80-83) have been reported in Tournaisian deposits of the Saalfeld area in Thuringia. Here, we document the anatomy of silicified stems of Sphenophyllum from these two regions. We compare them to the compression specimens from the same areas and we discuss their affinities and the new information they add to the evolution of Sphenophyllales.

\section{MATERIAL AND METHODS}

The new material described here consists of five anatomically preserved stems, three from Montagne Noire (MN) in France (Figs 1;3-5) and two from Thuringia in Germany (Figs 1; 6). 
Located in the southernmost part of the Massif Central, about $50 \mathrm{~km}$ west of Montpellier (Fig. 1A), the early Carboniferous localities of Montagne Noire have yielded abundant plant remains, with over 30 taxa of lycopsids, sphenopsids, ferns s.l., and lignophytes described to date. The anatomically preserved taxa occur in the Lydienne Formation, which consists of alternating beds of argillites and radiolarian cherts containing phosphatic nodules. Horizons containing plant fossils are considered middle Tournaisian in age (Tn2a-Tn2b) based on conodonts (Galtier et al. 1988). The Sphenophyllum specimens come from two different outcrops of the Lydienne Formation distant by about $5 \mathrm{~km}$, Puech de la Suque (MN201, MN864) and Coumiac (MN911). Specimen MN201 corresponds to the one previously illustrated by Galtier, who provided a general view comparable to Fig. 3B of the present paper (Galtier 1970: pl. 12, fig. 4, slide MN201-E02).

The two German specimens were collected in 1994-1995 at the quarry of Kahlleite (KLC) in Thuringia, not far from the historical locality of Saalfeld. The now-closed quarry is located $1 \mathrm{~km}$ south-west of the village Rödersdorf, on the eastern side of the Ziegenrück syncline (Weyer 1990; Fig. 1B). Plants occur in Rußschiefer, a marine formation with alternating grey shales containing nodules and red to dark brown silicified beds. The Rußschiefer occurs between a cephalopod limestone of early Tournaisian age ( $\mathrm{Tn} 1 \mathrm{~b})$ and turbiditic limestones containing calcareous foraminifers and algae from the photic zone indicating a Lower Visean age (Arundien; V1b-V2a). Plant remains are concentrated in the basal beds of the Rußschiefer and their age is estimated to be middle Tournaisian (Weyer 1990).

All specimens occurred within nodules that are generally up to $6 \mathrm{~cm}$ long and 1-2 cm wide. Specimen MN201 (within an exceptional $20 \mathrm{~cm}$ long nodule: Galtier et al. 1988: pl. I: 2) shows a remarkable type of preservation: the small fragment of Sphenophyllum stem occurs together with a small Clepsydropsis parvula Galtier, 1966 (Zygopteridales), a Lyginorachis Kidston, 1923 (Lyginopteridales), and leaf fragments inside the destroyed internal cortex of a large Clepsydropsis leclercqii Galtier, 1966 specimen (Fig. 3A). All other specimens occur isolated. Preparation of peel sections (Galtier \& Phillips 1999) did not yield adequate results, so the specimens were prepared using the thin-section technique (Hass \& Rowe 1999). Photos in transmitted or reflected light were taken using digital cameras (Sony XCD-U100CR) attached to an Olympus SZX12 stereomicroscope and to an Olympus BX51 compound microscope. Images were captured using Archimed software (Microvision Instruments) and plates were composed with Adobe Photoshop CS5 version 12.0 (Adobe Systems Inc.). Measurements were made with CellSens Entry 1.11. Average measurements are given for a minimum of 50 measures, otherwise, only a range of size is provided. The five specimens and 36 corresponding slides are deposited in the AMAP Research Unit, Collections de Paléobotanique, Université de Montpellier, under the accession numbers MN201, MN864, MN911, KLC3, and KLC4.

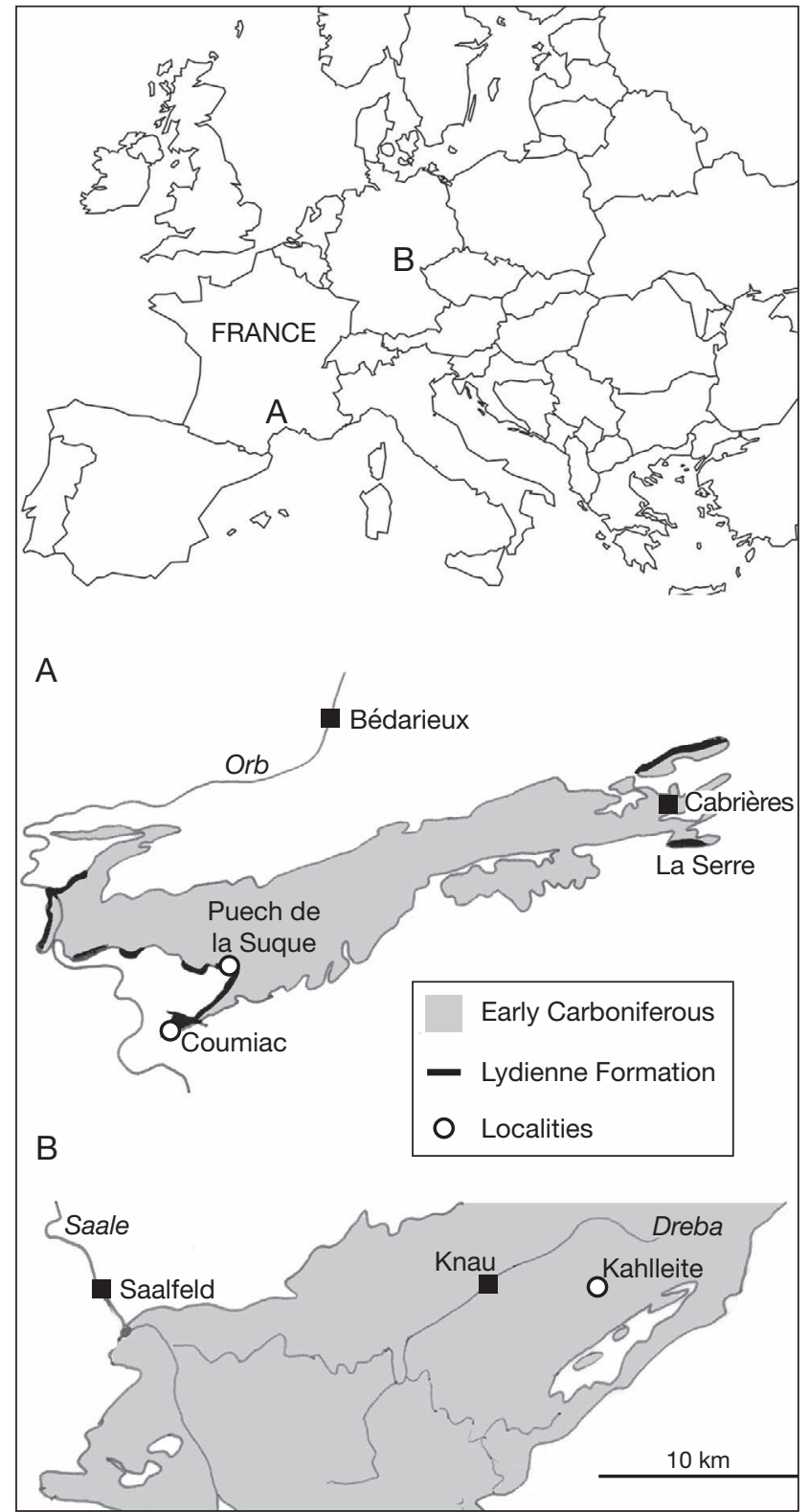

FIG. 1. - Maps showing the location of the localities in Southern France (A) and Thuringia, Germany (B). Detailed maps modified from Galtier et al. 1988 and Meyer-Berthaud \& Rowe 1997.

\section{DESCRIPTIONS}

The specimens display similar general anatomical characters; they are illustrated on different plates for clarity but described together.

\section{GENERAL ASPECT}

Stems are $2-10 \mathrm{~mm}$ in diameter. In transverse section, the central part of all specimens displays the sub-triangular actinostele typical of Sphenophyllum, with one protoxylem strand located at the extremity of each arm (Fig. 2). Vascular traces to the leaves are emitted from the extremity of the arms. MN201 and MN911 only have primary tissues (Figs 2A-E; 3 ; 4), while a small amount of secondary xylem is present in 

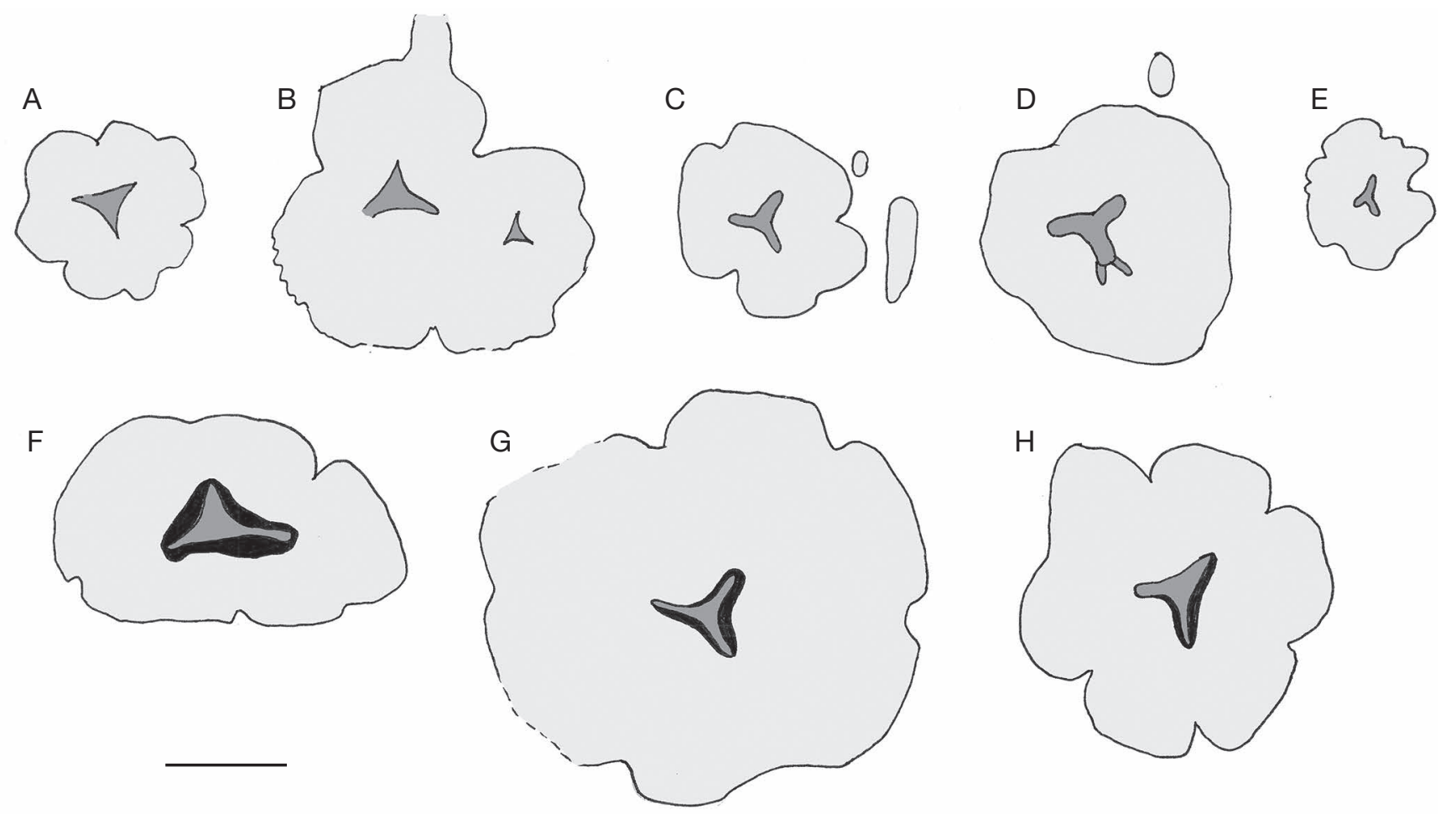

FIG. 2. - General aspect of the specimens in transverse section at the same scale. The primary xylem is in dark grey, the secondary xylem - when present - is in black. A, MN201(slide MN201-E2); B, same specimen as A at a level of branching (slide MN201-F1); C, largest axis resulting from the branching of MN911 with two leaf bases (slide MN911-A1); D, same axis as in C at another level with one leaf base and the production of two traces from one arm of the stele (slide MN911-A2); E, smallest axis resulting from the branching of MN911 (slide MN911-A2); F, MN864 showing secondary xylem all around the stele (slide MN864-C1); G, KLC3 showing a small amount of secondary xylem (slide KLC3-C); H, KLC4 showing a small amount of secondary xylem like KLC3 but a much smaller cortex (slide KLC4-B2). Scale bar: $2 \mathrm{~mm}$.

specimens MN864, KLC3, and KLC4 (Figs 2F-H; 5; 6). No primary or secondary phloem was identified. The outer part of the stem is composed of a ridged fibrous cortex.

\section{PRIMARY XYLEM}

The primary xylem forms an isodiametric triangle with concave sides that are about 1.5-2 mm (Figs 2; 3A-C; 4A-C; 5A, B; 6A-C, F) except in a lateral axis observed in MN911 which is a little smaller, with one side about $0.5 \mathrm{~mm}$ long (Figs 2E; $4 \mathrm{E})$. The location of protoxylem strands is often indicated by empty lacunae (Figs 3C; 4B, C; 5B; 6C) but, at some levels, the protoxylem is visible (e.g., Figs 4E-G; 6G). The smallest cells of the primary xylem interpreted as protoxylem range 6-10 $\mu \mathrm{m}$ wide in transverse section. Metaxylem cells are polygonal, with a more heterogeneous diameter, and range $10-50 \mu \mathrm{m}$. Successive sections along a length of $2 \mathrm{~cm}$ in specimen KLC4 indicate no rotation of the stele. Sections through the departure of leaf traces on specimen MN911 (Fig. 4D, G) show the ornamentation of primary xylem tracheids, which consists of scalariform to ovoid pitting (Fig. 4D) with a variable diameter $(c .10 \mu \mathrm{m})$ on both tangential and radial walls.

\section{SECONDARY XYLEM}

Two types of cells were identified in the secondary xylem. Radial files of thick-walled cells that are polygonal to rectangular in transverse section and much elongated in longitudinal section are interpreted as tracheids (Figs 5C, E; 6D, H).
Thin-walled cells that occur between some tracheid files in transverse section are interpreted as rays (arrows on Figs 5C; $6 \mathrm{D}, \mathrm{H})$. The secondary xylem is not much developed and mostly present in the bays between the arms formed by the primary xylem (Figs 5C; 6C, D; 6F, G). In KLC4, there are only 1-4 layers of secondary xylem cells and they are not present all around the primary xylem (Fig. 6C, D). The radial diameter of the tracheids ranges $2-20 \mu \mathrm{m}$ and the tangential diameter 10-40 $\mu \mathrm{m}$. KLC3 has up to seven layers of secondary xylem cells, with a diameter of 10-60 $\mu$ m radially and 10-80 $\mu \mathrm{m}$ tangentially (Fig. 6F-H). The most extensive development of secondary xylem was observed in specimen MN864, in which secondary xylem has started to entirely surround the primary xylem (Fig. 5B). It is up to nine layers of cells thick, with tracheids ranging 30-70 $\mu \mathrm{m}$ in diameter (Fig. 5C). Rays are uniseriate in all three specimens (Figs 5C; $6 \mathrm{D}, \mathrm{H})$. A series of longitudinal sections through MN864 did not yield any good ray in tangential or radial sections. In the radial section, some tracheids with a location corresponding to that of the secondary xylem show a faint ornamentation suggestive of a scalariform/tangentially elongated pitting (box on Fig. 5D corresponds to Fig. 5E).

\section{CORTEX}

The cortex is $1-4 \mathrm{~mm}$ thick in transverse section and shows conspicuous ridges (Figs 3B, D; 4A, B; 6A, B). At the levels with no emissions, there is typically a $3 \mathrm{n}$ symmetry but the 

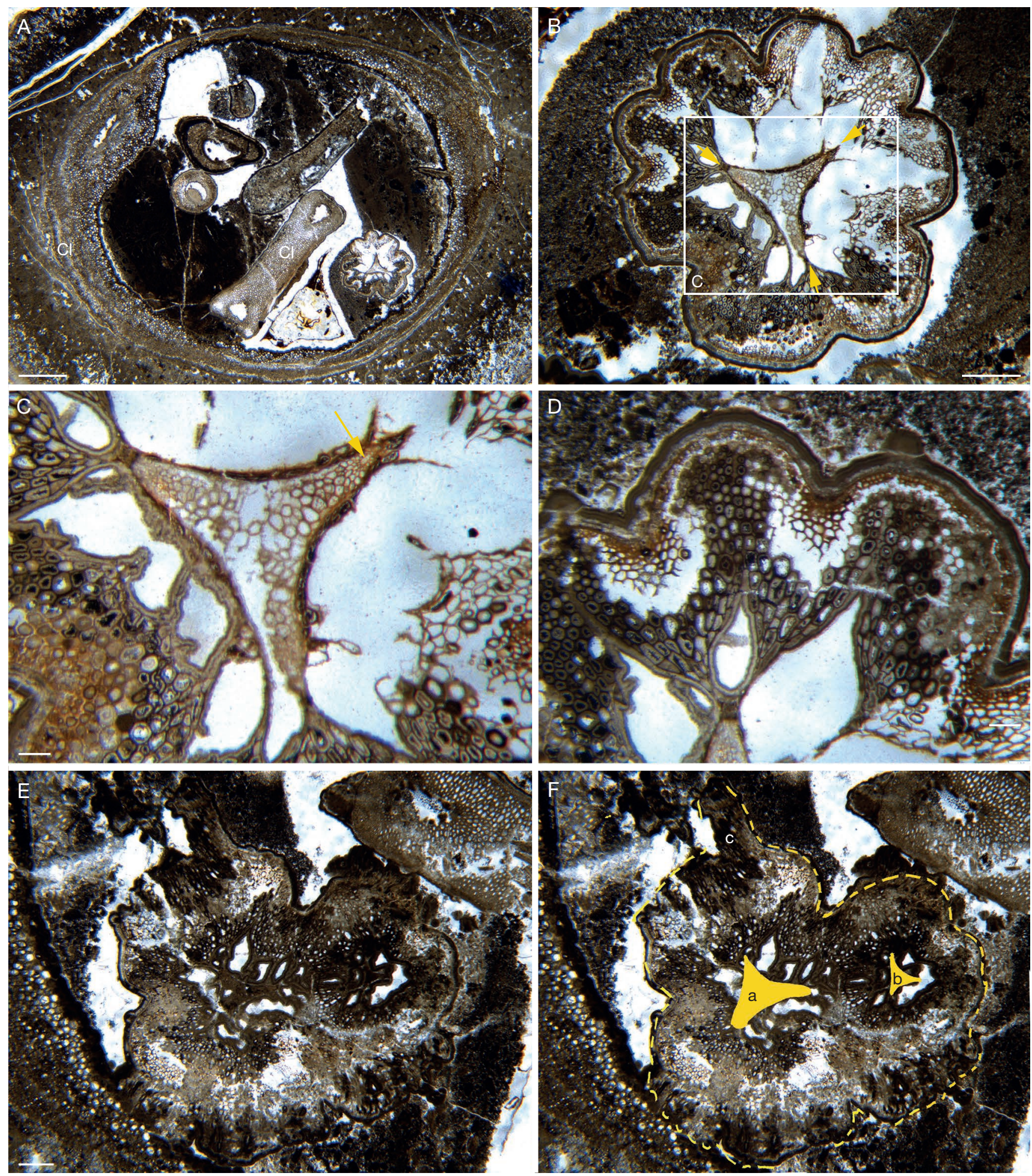

FIG. 3. - Specimen from Puech de la Suque, Montagne Noire, France (MN201): A, MN201-E2, general view showing several fragments of plants inside a partly decayed Clepsydropsis leclercqii Galtier, 1966 (CI). A young Sphenophyllum stem (S) in transverse view is present at the bottom right; B, MN201-E2, general view of the Sphenophyllum stem on A showing the ribbed cortex (C) and the triangular stele with three protoxylem strands (arrows); C, MN201-E2, detail of the triangular stele; note the small lacunae in the best preserved protoxylem strand (arrow); D, MN201-E2, detail of the cortex; E, same specimen as A-D (MN201-F1) at another level, less well preserved but showing branching; $\mathbf{F}$, same photo than $\mathbf{E}$ with the outline indicated in yellow, as well as the location of the primary xylem of the main axis (a) and of a lateral axis (b) also viewed in transverse section; the general outline of the cortex and oblique orientation of the tissue suggest the existence of another lateral organ towards the top of the photo (c); the tissues in the upper right corner correspond to part of the xylem of a Clepsydropsis Unger, 1856 rachis. Scale bars: A, 2 mm; B, E, $500 \mu \mathrm{m} ; \mathrm{C}, \mathrm{D}, 100 \mu \mathrm{m}$. 

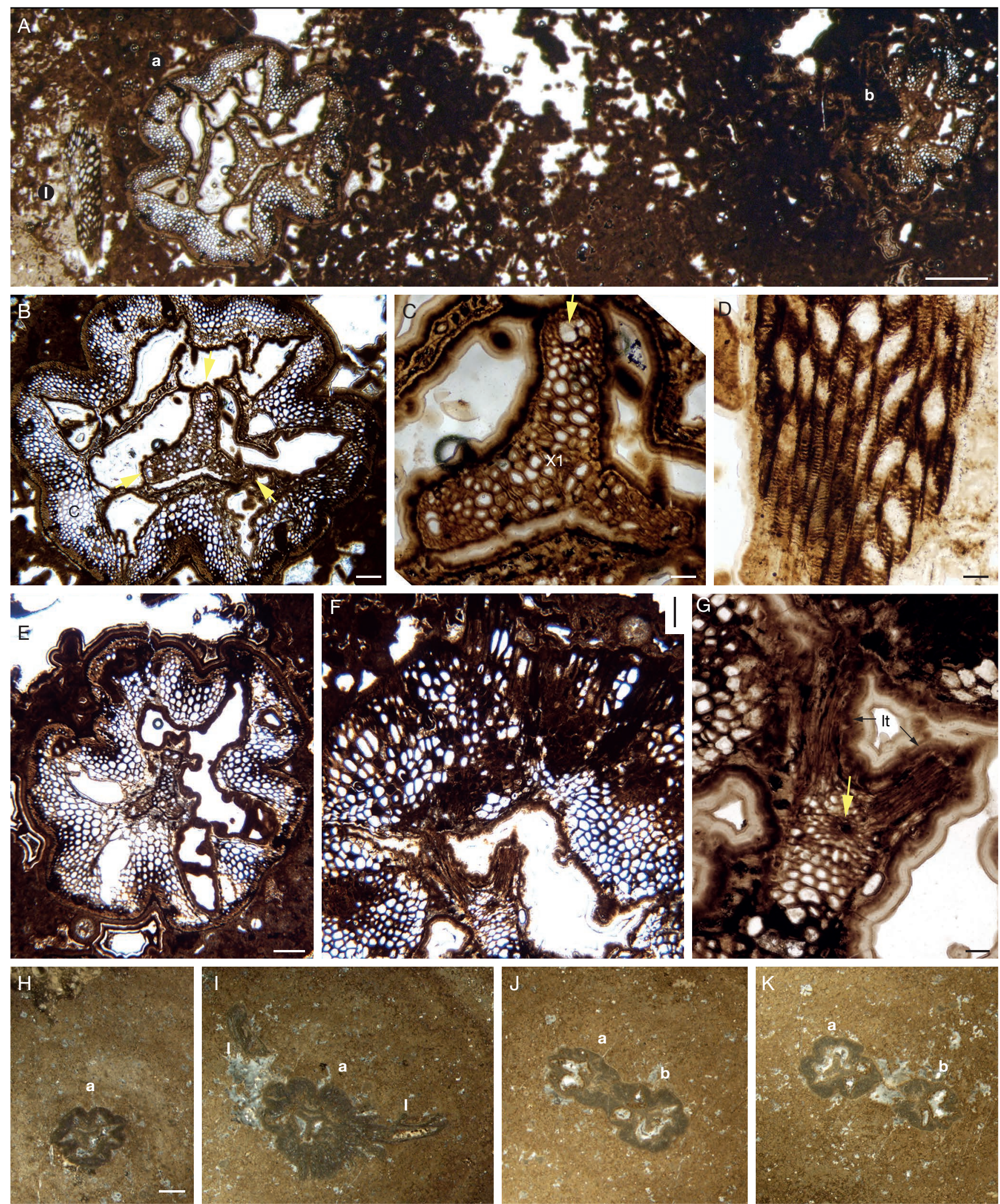

FIG. 4. - Specimen from Coumiac, Montagne Noire, France (MN911): A, slide MN911-A1, general view of the specimen above the level of branching, showing a main axis (a) on the left with a trace to a leaf (I) and a smaller axis (b) on the right; this section corresponds to the level 7 on Figure 7; B, slide MN911-A1, general view of the main axis in transverse section showing the cortex with six lobes and triangular primary xylem (arrows); C, slide MN911-A1, detail of the stele on A; note the presence of lacunae (arrow) at the extremity of each arm of the stele and the lack of secondary vascular tissues; D, slide MN911-A2, pitting on the primary xylem of an outgoing branch trace; E, slide MN911-A2, general view of the smaller axis shown on $\mathbf{A}$; note smaller size of the primary xylem compared to $\mathbf{B} ; \mathbf{F}$, slide MN911-A2, detail of the largest axis showing outgoing paired vascular traces at the extremity of the arm; G, slide MN911-A2, detail of F showing the protoxylem strand (arrow) and two outgoing traces (It); H-K, successive sections showing the branching of the axis; $\mathbf{H}$, below the division; I, node with leaves; J, branching; $\mathbf{K}$, branching complete. These photos correspond to the levels 1, 2, 4, and 5 on Figure 7 and to polished surfaces

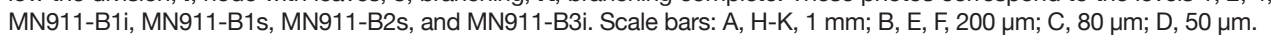



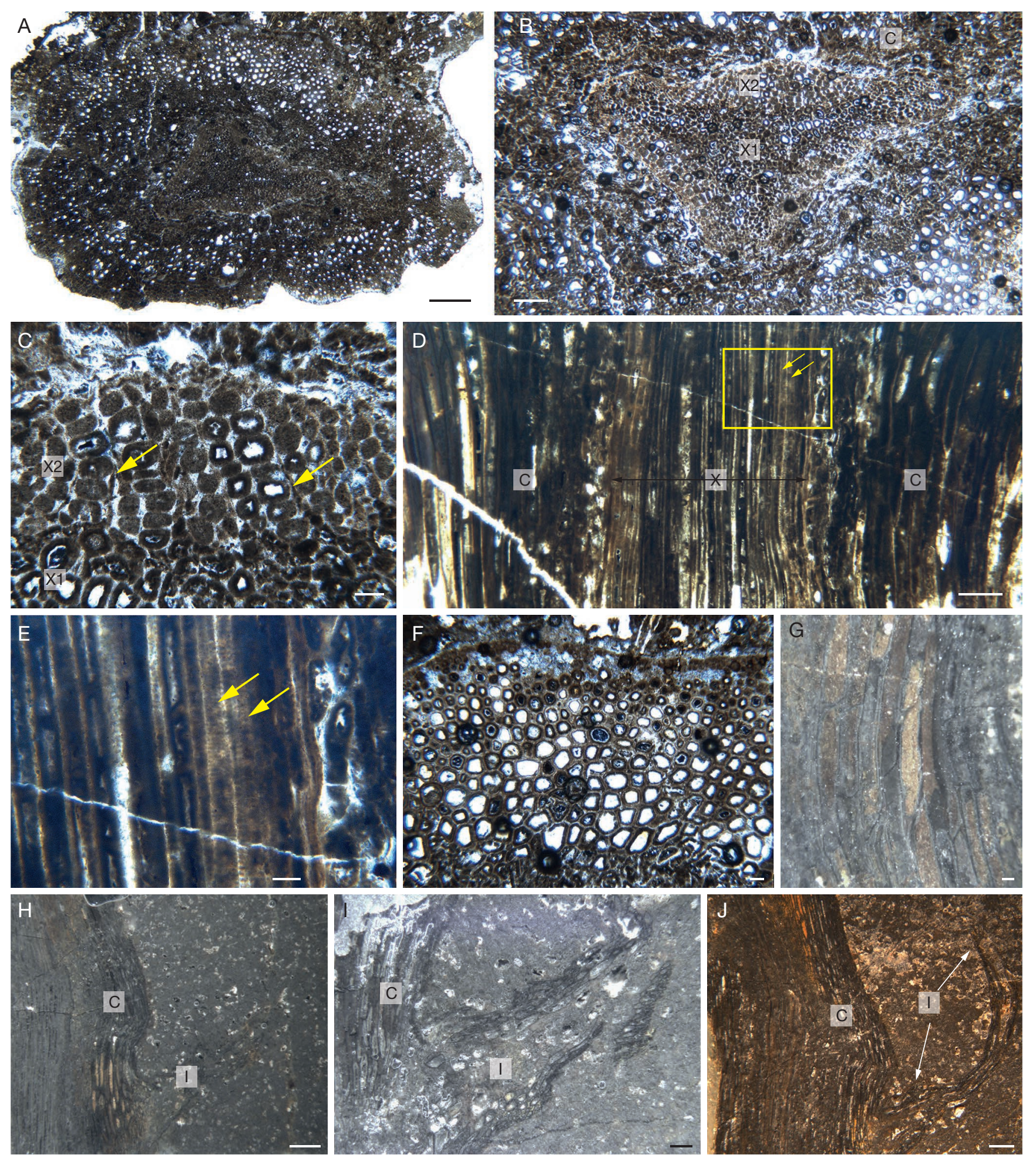

FIG. 5. - Specimen with secondary growth from Puech de la Suque, Montagne Noire, France (MN864): A, slide MN864-C1, general view of the specimen in transverse section; the cortex is flattened but the central vascular tissues are not distorted; B, slide MN864-C1, central part of the axis in transverse section showing the cortex (C), the triangular shape of the primary xylem (X1), the position of the protoxylem (arrows), and a little development of secondary xylem (X2); a lacuna is present at the location of the protoxylem in the top right arm of the stele; C, slide MN864-C1, detail of secondary xylem (X2) in transverse section, with row of tracheids and possible ray cells (arrows); D, slide MN864-C1, more or less radial section through the stem showing the central part composed of primary and secondary xylem (X) and cortex (C); E, slide MN864-A5, detail of the box on element D showing possible tangentially elongated pits on the radial wall of secondary xylem tracheids; $\mathbf{F}$, slide MN864-C1, detail of the cortex in transverse section showing a decrease in cell size and increase in wall thickness towards the periphery of the axis; G, slide MN864-A5, longitudinal section showing elongated cells of the cortex; $\mathbf{H}$, slide MN864-A5, longitudinal section at a node showing the cortex (C) and a leaf base (I) cut obliquely; I, slide MN864-A5, detail of the leaf base on $\mathbf{H}$; J, slide MN864-A6, longitudinal section at a node showing the cortex (C) and a leaf (I) showing its length and thickness. Scale bars: A, H, J, $500 \mu \mathrm{m} ; \mathrm{B}, \mathrm{I}, 200 \mu \mathrm{m} ; \mathrm{C}, \mathrm{E}-\mathrm{G}, 50 \mu \mathrm{m} ; \mathrm{D}, 250 \mu \mathrm{m}$. 
number of ridges varies vertically with the emission of laterals and leaves: Figure 3B shows a stem with eight unequal ridges, on Figure $4 \mathrm{~B}$ the axis has three main ridges that are each slightly divided, Figure $6 \mathrm{~A}$ and $\mathrm{B}$ show a change from 7 to 6 ridges at different levels in the same specimen. The inner part of the cortex is typically not preserved and is represented either by degraded cells (Fig. 5B) or, more commonly, by an empty region (e.g., Figs 3B; 4A, B; 6A, B, $\mathrm{F})$. There is no evidence of periderm, even in the specimens with secondary xylem (e.g., Fig. B). Cells of the outer cortex have a heterogeneous diameter, typically ranging 20-80 $\mu \mathrm{m}$, but up to $140 \mu \mathrm{m}$ in MN864. Cell diameter decreases towards the periphery of the axis while their wall thickness increases from 2 to $6 \mu \mathrm{m}$ (Figs 3D; 4B; 5F; 6E). In longitudinal section, these cortical cells are elongated and they are thus interpreted as fibers (Fig. 5D, G)

\section{LEAF TRACES}

Leaf traces are produced at certain levels in the axes. MN911 shows an example of emission from the extremity of one arm of the stele, with two distinct traces emitted at the same level (Fig. 4F-G). Transverse and longitudinal sections indicate that the leaf traces are emitted in whorls (e.g. Figs 4A, I; 5H-J; 7) and that they are at least $4.5 \mathrm{~mm}$ in length and $1 \mathrm{~mm}$ in width.

\section{BRANCHING}

At least two of the specimens show evidence of branching (Figs 3E, F; 4H-K). In specimen MN201, the main axis (Fig. 33B) divides to produce two axes, with a third lateral being produced slightly higher (Fig. 3E, F). In MN911, successive sections show evidence of dichotomous anisotone branching (Figs 4H-K; 7, level 4). About $2.6 \mathrm{~mm}$ above a whorl of leaves (Fig. 4I), the $4.5 \mathrm{~mm}$ wide axis divides into axes that are respectively 3 and $4 \mathrm{~mm}$ in diameter (a-b; Figs $4 \mathrm{~J}-\mathrm{K} ; 7$ ). The primary xylem of the smaller axis is also smaller. The angle of branching is about $67^{\circ}$ (Fig. 7).

\section{DISCUSSION}

\section{ASSIGNMENT OF THE SPECIMENS TO SPHENOPHYLLUM}

The specimens display all the characters present in stems of Sphenophyllum Brongniart, including a small axis diameter, marked internodes with whorled leaves in a multiple of three, a triangular actinostele, a ridged cortex, and some secondary xylem development (Williamson \& Scott 1895; Boureau 1964; Stewart \& Rothwell 1993; Taylor et al. 2009). Although they represent very short portions of stems, the new specimens are interesting in that they show some variability in terms of ontogenetic development. The size of the primary xylem of the main axis is relatively comparable in all specimens but they show different stages of secondary growth, from specimens that have only primary tissues to specimen MN864, in which secondary xylem surrounds the stele. None of the specimens has lost their primary cortex and it is impossible to know whether they had the potential to grow beyond this cortex and produce a secondary bark as has been demonstrated in several late Carboniferous species of Sphenophyllum (Stewart \& Rothwell 1993; Taylor et al. 2009 and references therein).

\section{COMPARISON WITH COMPRESSION SPECIMENS FROM \\ Montagne Noire AND Thuringia}

The Tournaisian floras of Montagne Noire and of the Saalfeld region have many genera in common (Rowe \& Galtier 1989) and compression specimens of Sphenophyllum have been found in both deposits. In the Montagne Noire region, all plant yielding localities contain Sphenophyllum, although their respective proportion is variable, from $0.6-2.4 \%$ only at the localities of St Nazaire and Coumiac to $15-20 \%$ at La Serre (Rowe \& Galtier 1989). The highly fragmentary preservation of the compression/impression specimens does not allow to assess specific affinities. Accordingly, the specimens have been referred to as Sphenophyllum sp. The diameter of the stems ranges $0.8-7 \mathrm{~mm}$, most being about $4 \mathrm{~mm}$ wide, and length extends up to $55 \mathrm{~mm}$. Internodes are 6-8 $\mathrm{mm}$ and 2-3 ridges are visible on the impressions/compressions, which is consistent with what is observed in the anatomically preserved specimens. Leaves are 3-11 mm long and their width decreases to form a thin apex. The exact number of leaves by nodes is uncertain but Rowe \& Galtier (1989) estimate it to be 6 to 12 , with leaves that divide in the first third of their length.

In Thuringia, compression/impression specimens of Sphenophyllum from the Saalfeld region have stems that are 1-7 mm wide, with 2-3 visible ridges (Meyer-Berthaud \& Rowe 1997). Leaves are poorly preserved but measure $1-8 \mathrm{~mm}$ in length and $1 \mathrm{~mm}$ in width. In some cases, they divide once and form two thin apices about $3 \mathrm{~mm}$ long. While a detailed comparison is not possible, these compression specimens also fit within the range of characters observed in the anatomically preserved specimens. One compression specimen from Thuringia shows a dichotomous division with a $60^{\circ}$ angle, quite comparable to what is observed in the anatomically preserved stems in MN911 from Montagne Noire.

According to Meyer-Berthaud \& Rowe (1997), the Thuringian specimens are different from those found in Montagne Noire based on the location of the division of leaves, which is more proximal in specimens from Montagne Noire. However, given the known variability of leaf morphology within species of the genus Sphenophyllum (Batenburg 1982; Bashforth \& Zodrow 2007) and the small size of the fragments from Montagne Noire and Thuringia it is not possible to conclude on the number of species represented in compressions.

\section{AfFinities}

After Renault $(1870,1873)$ confirmed the connection between permineralized stems and the well-known compressions of Sphenophyllum, several species of anatomically preserved stems were erected. Boureau (1964) recognized seven such species: S. plurifoliatum and S. insigne (Williamson \& Scott 1895), S. quadrifidum (Renault 1876, 1878; synonym of $S$. renaultii Phillips 1959), S. gilkineti (Leclercq 1924, 1925), S. perforatum and S. minus (Koopmans 1925), and S. constrictum (Phillips 

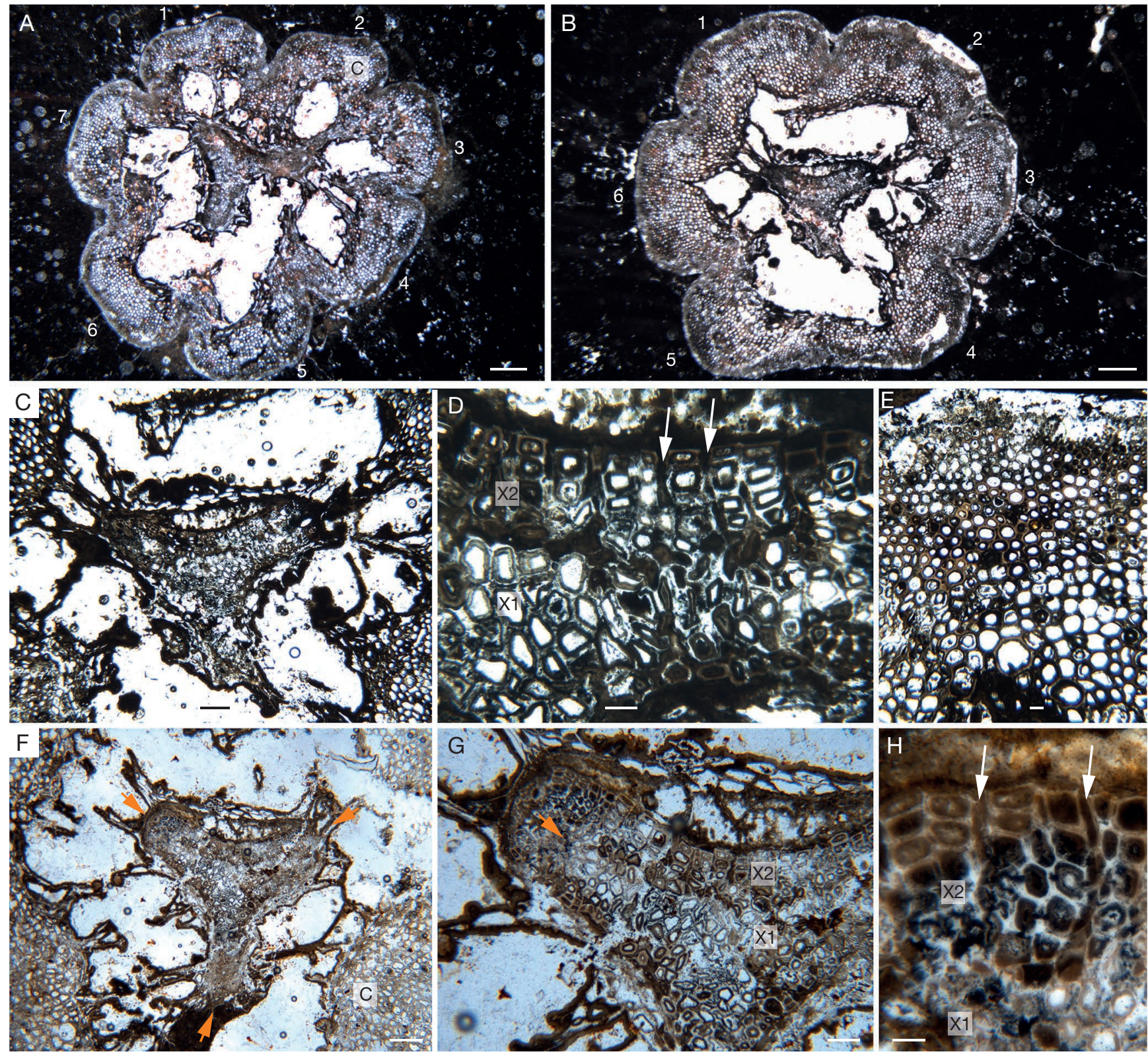

FIG. 6. - Specimens with secondary growth from Kahlleite, Germany (KLC4 \& KLC3): A, B, slides KLC4-A1 and KLC4-B1, general view of KLC4 in transverse sections at two different levels showing the triangular stele with three strands of protoxylem (arrows) and the outer cortex with 7 (A) or 6 (B) ridges; C, slide KLC4-B1, detail of the protostele in KLC 4 in transverse section showing a lacuna in at least one of the protoxylem locations; D, slide KLC4-B1, detail of the primary (X1) and secondary (X2) xylem in KLC4; note the files of secondary xylem tracheids separated by rays (arrows); E, slide KLC4-B1, detail of the outer cortex showing a decrease in cell diameter towards the outside of the stem (top of the image); $\mathbf{F}$, slide KLC3-C, centre of KLC3 in a region where the center is preserved; arrows indicate the tip of the three arms of the actinostele; G, slide KLC3-C, detail of the protostele of KLC3 showing a primary xylem pole (arrow) and the development of secondary xylem (X2) around the primary xylem (X1); H, slide KLC3-C, detail of the secondary xylem in KLC 3 showing tracheids and rays (arrows) in transverse section. Scale bars: A, B, $500 \mu \mathrm{m} ; \mathrm{C}, 200 \mu \mathrm{m} ; \mathrm{D}, \mathrm{H}, 50 \mu \mathrm{m} ; \mathrm{E}, 20 \mu \mathrm{m} ; \mathrm{F}, 250 \mu \mathrm{m} ; \mathrm{G}, 100 \mu \mathrm{m}$.

1959). Sphenophyllum gilkineti is very similar to $S$. plurifoliatum except for the unusual aspect of its wood, which is likely the result of disturbed cambial growth and not a specific character (Leclercq 1924; Schabilion \& Baxter 1971). S. perforatum and $S$. minus are also very similar to $S$. plurifoliatum (Phillips 1959). To the extent of our knowledge, no new species have been erected since 1959 and the three main species of anatomically preserved Sphenophyllum stems are thus S. insigne, $S$. plurifoliatum and $S$. renaultii. Among these species, the only one based on early Carboniferous specimens is Spheno- phyllum insigne, erected by Williamson \& Scott (1895) for specimens from Burntisland (Scotland) previously referred to as Asterophyllites insigne (Williamson 1874). According to Williamson and Scott and subsequent authors, S. insigne differs from other anatomically preserved Sphenophyllum by several points including: 1) the presence of a "canal" at each angle of the triangular primary xylem; 2) the scalariform thickenings on the radial wall of the tracheids; 3 ) the presence of rays throughout the secondary xylem; and 4) the occurrence of very large elements in the phloem that resemble sieve-cells. 
Early Carboniferous anatomically preserved specimens from the Saalfeld region (Fig. 1), close to and of similar age as those of Kahlleite quarry, were assigned to Sphenophyllum insigne by Solms-Laubach (1896: 80-83 and pl. V3-4). Galtier (1970) assigned his specimen from Montagne Noire (MN201 of this paper) to Sphenophyllum sp. due to the little amount of information available on its structure, but it "was likely that this plant belongs to the species Sphenophyllum insigne Will." The structure of the primary xylem in S. insigne is similar to that of all the specimens described in this paper, including the presence of lacunae at the location of the protoxylem, one of the main characters of that species according to Williamson \& Scott (1895). Regarding the wood anatomy, the new specimens are also more similar to $S$. insigne than to any other anatomically known species of Sphenophyllum (see also next paragraph). It is interesting to note that specimens of Sphenophyllum insigne from Burntisland show evidence of a well-developed periderm (Williamson \& Scott 1895) while the new specimens only have primary tissues in their cortex.

In the literature, most Sphenophyllum specimens of Early Carboniferous age are compressions/impressions that are assigned to the species $S$. tenerrimum (e.g., Hübers et al. 2014 and references therein). The species was first described by Ettingshausen (1852) and, more recently, revised by Havlena (1982). There has been a tendency to assign specimens to this species based solely on their age and, as a result, $S$. tenerrimum is now a widely defined species. Axes range 4-5 mm in diameter. The number of leaves per node is variable; Stur (1877) counts 9-12, while Boureau (1964) says that some specimens have only 6 and Storch \& Barthel (1980) count up to 18 . Leaves of $S$. tenerrimum are simple or divided once or twice. Axis diameter, number of leaves per node, and leaf length are compatible to that observed in the new specimens but leaf width is different $(0.3 \mathrm{~mm}$ for $S$. tenerrimum vs $1 \mathrm{~mm}$ for the new specimens). Other Early Carboniferous Sphenophyllales are based on fragmentary material and differ from $S$. tenerrimum mostly in details of leaf characters that cannot be observed on the anatomically preserved specimens.

Dozens of species of Sphenophyllum have been described to date and the delimitation of species, as well as the correspondence between compression and anatomically preserved forms, has always been problematic (Good 1973; Batenburg 1982). "Compression species" are mostly based on leaf characters that often cannot be observed in anatomically preserved stems and are known to be highly variable, even within the same specimen. Bashforth \& Zodrow (2007), for example, illustrated a $2 \mathrm{~m}$ long compression specimen of Sphenophyllum costae, in which leaves borne on axes of different orders have a very different morphology. With highly fragmentary specimens such as the compressions and silicified stems from Montagne Noire and Thuringia, it is impossible to assess the position in the plant and any identification based on the leaves would be questionable. Inversely, differences in anatomy such as the ones listed earlier to identify Sphenophyllum insigne (e.g., canals in the protoxylem, wood anatomy) cannot be observed on compression/impression specimens. In this context, we consider that our new specimens are to be compared to Sphenophyllum insigne. The compressions from the same localities might represent the same taxon or several taxa having a similar stem anatomy.

\section{SECONDARY XYLEM ANATOMY IN SPHENOPHYLLALES}

The secondary xylem of Sphenophyllum has long been a subject of interest because its anatomy differs from that found in other known taxa with secondary xylem, such as other sphenophytes, the lignophytes, or the lycophytes. Most of our knowledge on this peculiar wood anatomy comes from the detailed studies conducted on the Late CarboniferousPermian species Sphenophyllum plurifoliatum (e.g., Renault 1876; Williamson \& Scott 1895; Baxter 1948; Reed 1949; Eggert \& Gaunt 1973; Cichan 1985, 1986; Cichan \& Taylor 1982). In this species, the secondary xylem is well developed. There is typically a conspicuous difference in aspect between the fascicular (opposite the primary xylem arms) and interfascicular (between the arms) regions. It is, however, interesting to note that such a zonation can be obscured in Sphenophylllum stems in which cambial activity has been disrupted (Schabilion \& Baxter 1971). Tracheids are typically larger in interfascicular regions but the anatomy is otherwise the same than in fascicular regions (e.g., Renault 1876; Williamson \& Scott 1895; Cichan 1985). The secondary xylem of $S$. plurifoliatum contains a unique system of vertical parenchyma cells located at the corners of tracheids and connected to the rays (Renault 1876; Williamson \& Scott 1895; Eggert \& Gaunt 1973; Cichan 1985). Its secondary xylem tracheids can reach $30 \mathrm{~mm}$ in length and are among the longest tracheids ever described (Cichan \& Taylor 1990). The cambium is interpreted as determinate; its unifacial (Cichan \& Taylor 1990; E. Taylor 1990) vs bifacial (Eggert \& Gaunt 1973) nature is still disputed.

While we did not observe vertical parenchyma cells in the new specimens, it is possible that it is due to a combination of the little amount of wood produced by the axes and a bad preservation of parenchymatous cells in general. On the other hand, it must be noted that the peculiar anatomy observed in late Carboniferous and Permian Sphenophyllum has not been reported in older representatives of the Sphenophyllales. In the Devonian genera that have secondary growth, Rotafolia (Wang et al. 2006b) and Hamatophyton (Wang et al. 2006a), radially aligned tracheids interpreted as secondary xylem are present but there is no parenchymatous vertical system. Rays have not been observed in Hamatophyton and are rare in Rotafolia (Wang et al. 2006b). Pleurorhizoxylon, a recently described anatomically preserved stem from the Late Devonian of China (Zhang et al. 2018), shows significant similarities with the Sphenophyllales but does not have a parenchymatous vertical system in its wood. The anatomy of Devonian stems of Sphenophyllum (Huang et al. 2018 and refs therein) and of Xihuphyllum (Huang et al. 2017) is unknown. The question thus remains as to when exactly the unusual wood anatomy that occurs in younger taxa such as Sphenophyllum plurifoliatum did arise. 


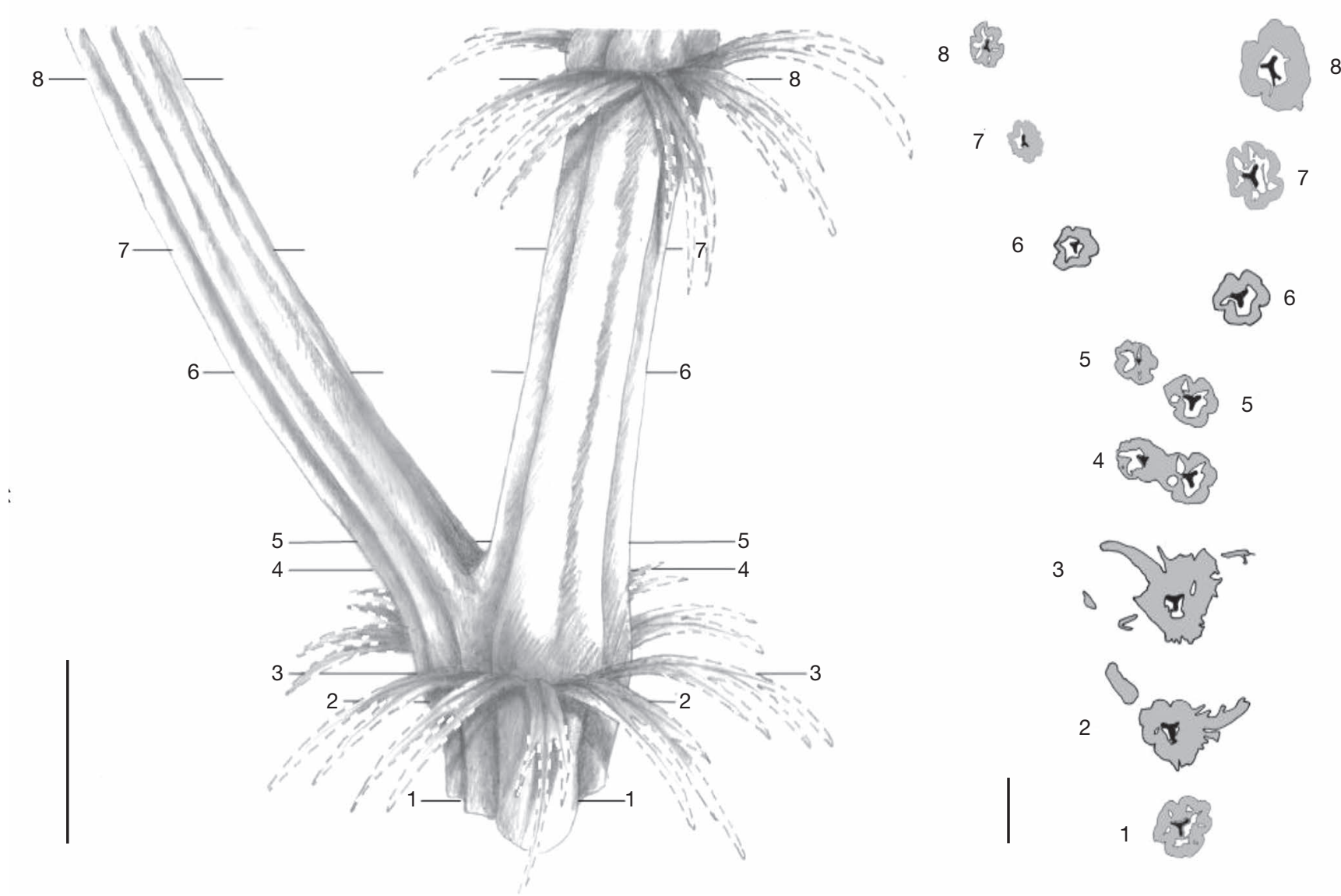

FIG. 7. - Reconstruction of MN911 at the level of branching based on a series of transverse sections. Because only the base of the leaves is well known, their tips are represented in dashed lines. Sections 1-6 correspond to polished surfaces MN911-B1i, MN911-B1s, MN911-B2i, MN911-B2s, MN911-B3i, and MN911B3s; sections 7 and 8 correspond to slides MN911-A1 and MN911-A2. Artwork by Bernard Terreaux.

In their description of Sphenophyllum plurifoliatum and S. insigne, Williamson \& Scott (1895) noted that the wood of the latter differs by the fact that "occasionally isolated cells occur at the corners of tracheae [tracheids], but, as a rule, the parenchyma of the wood takes the form of continuous rays". These continuous medullary rays were considered by Williamson and Scott as one of the distinctive features of S. insigne. Other descriptions including that of Tournaisian specimens from Saalfeld by Solms-Laubach (1896), indicate that Sphenophyllum insigne had a much more "classic" wood anatomy, with longer radial rays and only rare occurrences of the vertical parenchymatous cells ("upright cells" of Cichan 1985). Re-observation of slides of S. insigne from the early Carboniferous of Scotland kept in the collections of the University of Kansas support these descriptions. The wood anatomy of $S$. insigne thus corresponds more to what is observed in the new specimens from Montagne Noire and Thuringia and supports Cichan's (1985) interpretation that the unusual anatomy of $S$. plurifoliatum is likely derived from a more typical ray system.

Another important thing to consider is the size of the conductive elements in Sphenophyllales. In S. plurifoliatum the conductive cells of the wood are not only very long (up to $30 \mathrm{~mm}$ ) but also very wide, ranging $130-160 \mu \mathrm{m}$ in average diameter from the center to the outer part of the stems
(Cichan 1985, 1986). As a result, the conductive properties of the wood are often estimated to be comparable to those of extant angiosperm vines and lianas (Cichan 1986; Wilson 2013). On the other hand, in Devonian representatives of the Sphenophyllales for which anatomy is known the tracheids are much smaller, with maximum diameters of 70 and $45 \mu \mathrm{m}$ respectively in Hamatophyton and Rotafolia (Wang et al. 2005, 2006a, b). The early Carboniferous specimens described in this paper and those assigned to Sphenophyllum insigne by previous authors have maximum tracheid diameters of about $80-110 \mu \mathrm{m}$ in the interfascicular zones and 50-60 $\mu \mathrm{m}$ in the fascicular zones (Williamson \& Scott 1895; ALD personal observation). Finally, there is also some variation in the pitting of the wood tracheids in Sphenophyllales. While the late Carboniferous species of Sphenophyllum have crowded elliptical to circular bordered pits, Sphenophyllum insigne is characterized by tangentially elongated pits ("scalariform pitting" of Williamson \& Scott). The Devonian genera Hamatophyton, Rotafolia, and Pleurorbizoxylon all show a combination of "scalariform" to elliptical bordered pits.

This short review advocates that there is an interesting disparity between the wood of the oldest and youngest plants assigned or closely related to the Sphenophyllales. Given their different anatomy, the hydraulic and mechanical properties 
of the wood of Late Devonian and early Carboniferous taxa could differ significantly from those of younger representatives like $S$. plurifoliatum, with important implications for the reconstruction of their habit and ecology.

\section{CONCLUSIONS}

We describe new anatomically preserved specimens of Sphenophyllum from the early Carboniferous (middle Tournaisian) of France and Germany. The specimens are short portions of stems comparable to Sphenophyllum insigne Williamson, a species previously described in Early Carboniferous deposits of Scotland and Germany. They likely represent the same taxon than the stems found in compressions at the two localities. The secondary xylem of Devonian-Early Carboniferous members of the Sphenophyllales differs from the younger "classic" species in terms of organization and tracheid diameter and ornamentation, suggesting different hydraulic and mechanical properties. Although Sphenophyllum has been featured in some of the oldest palaeobotanical publications and Williamson \& Scott wrote 123 years ago that "our knowledge of the structure of Sphenophyllum is now fairly complete", it appears that there is still much work to be done to fully understand the taxonomic diversity, evolution, and biology of this emblematic genus.

\section{Acknowledgements}

We thank Marion Lacand (Montpellier) for her help in preparing additional slides and Bernard Terreaux (Taillet) for the reconstruction drawing, and Rudolph Serbet (Lawrence) for access to the $S$. insigne slides kept at the University of Kansas. We also thank Ronny Rößler and an anonymous reviewer for comments and suggestions that helped improve this paper. ALD acknowledges funding from LabEx CeMEB (Exploratory Project MARCON - MARine and CONtinental ecosystems survival strategies in relation to global changes at the D-C boundary) during the course of this research.

\section{REFERENCES}

BAshFORTH A. R. \& ZODROW E. L. 2007. — Partial reconstruction and palaeoecology of Sphenophyllum costae (Middle Pennsylvanian, Nova Scotia, Canada). Bulletin of Geosciences 82: 365-382.

Batenburg L. H. 1977. - The Sphenophyllum species in the Carboniferous flora of Holz (Westphalian D, Saar Basin, Germany). Review of Palaeobotany and Palynology 24: 69-100. https://doi. org/10.1016/0034-6667(77)90005-7

BATENBURG L. H. 1981. - Vegetative anatomy and ecology of Sphenophyllum zwickaviense, S. emarginatum, and other "compression species" of Sphenophyllum. Review of Palaeobotany and Palynology 32: 275-313. https://doi.org/10.1016/0034-6667(81)90008-7

Batenburg L. H. 1982. — "Compression species" and "petrifaction species" of Sphenophyllum compared. Review of Palaeobotany and Palynology36:335-359. https://doi.org/10.1016/0034-6667(82)90028-8

BAXTER R. W. 1948. - A Study of the Vegetative Anatomy of the Genus Sphenophyllum from American Coal Balls. Annals of the Missouri Botanical Garden 35: 209-231. https://doi. org/10.2307/2394531
Boureau E. 1964. — Traité de Paléobotanique. Tome III, Sphenophyta Noeggerathiophyta. Masson et Cie, Paris, 544 p.

Brongniart A. T. 1828. - Prodrome d'une histoire des végétaux fossiles. F. G. Levrault, Paris, 223 p. https://doi.org/10.5962/ bhl.title. 62840

CiCHAN M. A. 1985. - Vascular cambium and wood development in Carboniferous plants. II. Sphenophyllum plurifoliatum Williamson and Scott (Sphenophyllales). Botanical Gazette 146: 395-430. https://doi.org/10.1086/337539

Cichan M. A. 1986. - Conductance in the wood of selected Carboniferous plants. Paleobiology 12: 302-310. https://doi. org/10.1017/S0094837300013804

Cichan M. A. \& TAYlor T. N. 1982. - Vascular Cambium development in Sphenophyllum: a Carboniferous arthrophyte. IAWA Bulletin n.s. 3: 155-160. https://doi.org/10.1163/2294193290000830

Cichan M. A. \& TAYLOR T. N. 1990. - Evolution of cambium in geologic time - A reappraisal, in IQBAL M. (ed.), The Vascular Cambium. John Wiley and Sons Inc., New York: 213-228.

CHEN Q.-S. 1988. - Fossil plants Sphenophyllales from Late Devonian Xihu Formation in Xiaoshan, Zhejiang. Acta Palaeontologica Sinica 27: 404-415.

EgGert D. A. \& GAunT D. D. 1973. - Phloem of Sphenophyllum. American Journal of Botany 60: 755-770. https://doi. org/10.1002/j.1537-2197.1973.tb07588.x

EtTingshausen C. 1852. - Die Steinkohlenflora von Stradonitz in Böhmen. Abhandlungen der Kaiserlich-Königlichen Geologischen Reichsanstalt 1 (3): 1-18.

GALTIER J. 1970. - Recherches sur les végétaux à structure conservée $d u$ Carbonifere inférieur français. Paléobiologie continentale, vol. 1 (4). Université des sciences et techniques, Montpellier: 1-221.

Galtier J. \& DAVIERO V. 1999. - Structure and Development of Sphenophyllum oblongifolium from the Upper Carboniferous of France. International Journal of Plant Sciences 160: 1021-1033. https://doi.org/10.1086/314193

Galtier J. \& PHILlips T. L. 1999. — The acetate peel technique, in JONES T. P. \& Rowe N. P. (eds), Fossil Plants and Spores: Modern Techniques. Geological Society, London: 67-70.

Galtier J., Meyer-Berthaud B. \& Rowe N. P. 1988. — Tournaisian plants from the "Lydiennes" Formation of the Montagne Noire (France). Courier Forschungsinstitut Senckenberg 100: 109-117.

GOOD C. W. 1973. Studies of Sphenophyllum shoots: Species delimitation within the taxon Sphenophyllum. American Journal of Botany 60: 929-939. https://doi.org/10.1002/j.1537-2197.1973. tb05992.x

Hass H. \& Rowe N. P. 1999. - Thin sections and wafering, in JONES T. P. \& Rowe N. P. (eds), Fossil Plants and Spores: Modern Techniques, Geological Society, London, UK: 76-81.

HAVLENA V. 1982. - Sphenophyllum tenerrimum and other species of Sphenophyllum in the Namurian of the Ostrava-Karviná coalfield (Upper Silesian basin). Palaeontographica Abteilung B 184: 1-22.

Huang P., Liu L., Deng Z., Basinger J. F. \& Xue J. 2017. Xihuphyllum, a novel sphenopsid plant with large laminate leaves from the Upper Devonian of South China. Palaeogeography Palaeoclimatology Palaeoecology 466: 7-20. https://doi.org/10.1016/j. palaeo.2016.11.004

HuAng P., LiU L., Qin M., LiU L., Deng Z., Wang D., Basinger J. F. \& XUE J. 2018. - New Sphenophyllum plant from the Upper Devonian of Zhejiang Province, China. Historical Biology 30: 917-927. https://doi.org/10.1080/08912963.2017.1322077

Hübers M., Bomfleur B., Krings M., Pott C. \& Kerp H. 2014. - A reappraisal of Mississippian (Tournaisian and Visean) adpression floras from central and northwestern Europe. Zitteliana 54: 39-52. https://doi.org/10.5282/ubm/epub.22322

Koopmans R. G. 1925. - Researches on the Flora of the Coal-Balls from the "Finefrau-Nebenbank" Horizon in the Province of Limburg (The Netherlands). Geologisch Bureau voor het Nederlandsche Mijngebied Heerlen, 53 p. 
LECLERCQ S. 1924. - Observations nouvelles sur la structure anatomique de quelques végétaux du houiller Belge. Académie royale de Belgique, Bulletins de la Classe des Sciences: 352-354.

LECLERCQ S. 1925. - Introduction à l'étude anatomique des végétaux houillers de Belgique. Les coal-balls de la couche Bouxharmont des charbonnages de Wérister. Annales de la Société géologique de Belgique, mémoires in $-4^{\circ}$, volume $6: 79 \mathrm{p}+40 \mathrm{pls}$.

LECLERCQ S. 1957. — Étude d'une fructification de Sphénopside à structure conservée du Devonian supérieur. Mémoires de l'Académie royale de Belgique, Classe des Sciences, vol. 14: 1-39.

Li X.-X., CAI C.-Y. \& WANG Y. 1995. - Hamatophyton verticillatum (Gu \&Zhi) emend.: a primitive plant of Sphenopsida from the Upper Devonian-Lower Carboniferous in China. Palaeontographica Abteilung B 235: 1-22.

Meyer-Berthaud B. \& Rowe N. P. 1997. - A Lower Carboniferous plant assemblage from Thuringia (Germany): Compressions. Review of Palaeobotany and Palynology 97: 361-379. https://doi. org/10.1016/S0034-6667(96)00075-9

Phillips T. L. 1959. - A new sphenophyllalean shoot system from the Pennsylvanian. Annals of the Missouri Botanical Garden 46 (1-2): 1-17. https://doi.org/10.2307/2394565

REED F. D. 1949. - Notes on the anatomy of two Carboniferous plants Sphenophyllum and Psaronius. Botanical Gazette 110: 501510. https://doi.org/10.1086/335550

RenAult B. 1870. - Mémoire sur l'organisation de rameaux silicifiés appartenant probablement à un Sphenophyllum. Comptes-rendus hebdomadaires des séances de l'Académie des Science 70: 11581160. https://gallica.bnf.fr/ark:/12148/bpt6k30279/f1158.item

RENAULT B. 1873. - Recherches sur l'organisation des Sphenophyllum et des Annularia. Annales des Sciences naturelles, 5ème série, 18 : 5-22. https://gallica.bnf.fr/ark:/12148/bpt6k445309g/f2.item

RENAULT B. 1876. - Nouvelles recherches sur la structure des Sphenophyllum et sur leurs affinités botaniques. Annales des Sciences naturelles, Geme série, 4: 277-310. https://gallica.bnf.fr/ ark:/12148/bpt6k5525254j/f280.item

RENAULT B. 1878. - Recherches sur la structure et les affinités botaniques des végétaux silicifiés recueillis aux environs d'Autun et de Saint-Étienne. Publication de la Société éduenne. Dejussieu père et fils, Autun, 216 p. https://gallica.bnf.fr/ark:/12148/bpt6k55338971

Rowe N. P. \& Galtier J. 1989. - A Lower Carboniferous plant assemblage from La Serre (Montagne Noire, France). Part I. Review of Palaeobotany and Palynology 63: 91-115. https://doi. org/10.1016/0034-6667(89)90034-1

SCHABILION J. T. \& BAXTER R. W. 1971. - A reconsideration of the Pennsylvanian Arthrophyte Sphenophyllum gilkineti Leclercq. Botanical Gazette 132: 304-307. https://www.jstor.org/stable/2474167

SOlMS-LAUBACH H. 1896. - Uber die seinerzeit von Unger beschriebenen strukturbietenden Pflanzenreste des Unterkulms von Saalfeld in Thüringen. Abhandlungen der Königlich Preussischen geologischen Landesanstalt 23: 1-100.
Stewart W. \& Rothwell G. W. 1993. - Paleobotany and the Evolution of Plants. 2nd edition. Cambridge University Press, Cambridge, $521 \mathrm{p}$.

STORCH D. \& BARTHEL M. 1980. — Adventivwurzeln bei Sphenophyllum-Arten. Zeitschrift für Geologische Wissenschaften 8: 1571-1579.

STUR D. 1877. - Die Culm-Flora der Ostrauer und Waldenburger Schichten. Abhandlungen der Kaiserlich-Königlichen Geologischen Reichsanstalt 8 (2): 108-214.

TAYLOR E. L. 1990. - Phloem evolution: an appraisal based on the fossil record, in BeHnKe H. D. \& Sjolund R. D. (eds), Sieve Elements: Comparative Structure, Induction and Development. Springer, Berlin: 285-298.

TaYlor T. N., TaYlor E. L. \& Krings M. 2009. - Paleobotany: The Biology and Evolution of Fossil Plants. $2^{\text {nd }}$ ed. Academic Press, Amsterdam, $1230 \mathrm{p}$.

WANG Y. 1993. - First discovery of Eviostachya hoegii Stockmans from Wutung Formation in China. Acta Palaeontologica Sinica 32: 430-438.

Wang D. M., HaO S. G. \& WANG Q. 2005. - Rotafolia songziensis gen. et comb. nov., a sphenopsid from the Late Devonian of Hubei, China. Botanical Journal of the Linnean Society 148: 21-37. https://doi.org/10.1111/j.1095-8339.2005.00387.x

WANG D. M., HAO S. G., TiAn L. \& XUE J. Z. 2006a. - Further study of the Late Devonian sphenopsid Hamatophyton verticillatum from China. International Journal of Plant Sciences 167: 885-896. https://doi.org/10.1086/503818

WANG D. M., HAO S. G., WANG Q. \& XUE J.Z. 2006b. — Anatomy of the Late Devonian sphenopsid Rotafolia songziensis, with a discussion of stelar architecture of the Sphenophyllales. International Journal of Plant Sciences167: 373-383. https://doi.org/10.1086/499115

WEYER 1990. — Field excursions to Thuringia (Germany). IUGS working group of the Devonian-Carboniferous boundary Guidebook: 14-17.

Williamson W. C. 1874. - On the organization of the fossil plants of the Coal-measures. Part V: Asterophyllites. Philosophical Transactions of the Royal Society London B 164: 41-81. https:// doi.org/10.1098/rstl.1874.0003

WilliamSON W. C. \& SCOTT D. H. 1895. — Further observations on the organisation of the fossil plants of the coal-measures. Part I. Calamites, Calamostachys and Sphenophyllum. Philosophical Transactions of the Royal Society London B 185: 863-959. https:// doi.org/10.1098/rspl.1894.0021

WILSON J. P. 2013. - Modeling 400 million years of plant hydraulics. Paleontological Society Papers 19: 175-194. https://doi. org/10.1017/S1089332600002734

Zhang Y., Berry C. M., Wang D., Xue J. \& Liu L. 2018. Pleurorhizoxylon yixingense gen. et sp. nov., a Euphyllophyte axis with anatomically preserved adventitious roots from the Late Devonian of South China. International Journal of Plant Sciences 179: 523-540. https://doi.org/10.1086/698710 